\title{
Article
}

\section{Acetaldehyde Adsorption Characteristics of Ag/ACF Composite Prepared by Liquid Phase Plasma Method}

\author{
Byung-Joo Kim ${ }^{1}{ }^{\circledR}$, Kay-Hyeok An ${ }^{1}$, Wang-Geun Shim ${ }^{2}$, Young-Kwon Park ${ }^{3}$, Jaegu Park ${ }^{4}$, Heon Lee ${ }^{4}$ \\ and Sang-Chul Jung ${ }^{4, *}$ \\ 1 Department of Carbon \& Nanomaterials Engineering, Jeonju University, Jeonju 55069, Korea; \\ kimbj2015@gmail.com (B.-J.K.); khandragon@jj.ac.kr (K.-H.A.) \\ 2 Department of Chemical Engineering, Sunchon National University, Suncheon 57922, Korea; \\ wgshim@sunchon.ac.kr \\ 3 School of Environmental Engineering, University of Seoul, Seoul 02504, Korea; catalica@uos.ac.kr \\ 4 Department of Environmental Engineering, Sunchon National University, Suncheon 57922, Korea; \\ worn0623@gmail.com (J.P.); honylee@hanmail.net (H.L.) \\ * Correspondence: jsc@sunchon.ac.kr; Tel.: +82-61-750-3814
}

Citation: Kim, B.-J.; An, K.-H.; Shim, W.-G.; Park, Y.-K.; Park, J.; Lee, H.; Jung, S.-C. Acetaldehyde Adsorption Characteristics of $\mathrm{Ag} / \mathrm{ACF}$ Composite Prepared by Liquid Phase Plasma Method. Nanomaterials 2021, 11, 2344. https://doi.org/10.3390/nano11092344

Academic Editor: Gheorghe Dinescu

Received: 4 August 2021

Accepted: 7 September 2021

Published: 9 September 2021

Publisher's Note: MDPI stays neutral with regard to jurisdictional claims in published maps and institutional affiliations.

\begin{abstract}
Ag particles were precipitated on an activated carbon fiber (ACF) surface using a liquid phase plasma (LPP) method to prepare a Ag/ACF composite. The efficiency was examined by applying it as an adsorbent in the acetaldehyde adsorption experiment. Field-emission scanning electron microscopy and energy-dispersive X-ray spectrometry confirmed that Ag particles were distributed uniformly on an ACF surface. X-ray diffraction and X-ray photoelectron spectroscopy confirmed that metallic silver $\left(\mathrm{Ag}^{0}\right)$ and silver oxide $\left(\mathrm{Ag}_{2} \mathrm{O}\right)$ precipitated simultaneously on the ACF surface. Although the precipitated Ag particles blocked the pores of the ACF, the specific surface area of the Ag/ACF composite material decreased, but the adsorption capacity of acetaldehyde was improved. The AA adsorption of ACF and Ag/ACF composites performed in this study was suitable for the Dose-Response model.
\end{abstract}

Keywords: liquid phase plasma; Ag/ACF composite; acetaldehyde; specific surface area; adsorption capacity; dose response model

\section{Introduction}

Volatile organic compounds (VOC) is a generic term for liquid or gaseous organic compounds that can evaporate easily into the atmosphere because of their low boiling point. These compounds are diverse, ranging from solvents commonly used in industry to organic gases discharged from chemical and pharmaceutical factories or plastic drying processes [1,2]. Liquid fuels with low boiling points, paraffin, olefins, aromatic compounds, and other hydrocarbons are commonly used. Among them, acetaldehyde (AA) is one of 35 specific air-hazardous substances in Korea and has a reference concentration for trace emission of 0.01 ppm because it is harmful to the human body [3,4]. Acetaldehyde can cause respiratory paralysis, convulsion, and corneal injury [5].

Adsorption, photocatalytic oxidation, plasma oxidation, and the like are known as treatment methods for the removal of acetaldehyde. Since it has problems such as limited decomposition reaction, generation of by-products (photocatalytic oxidation), and generation of nitrogen dioxide and ozone (plasma oxidation), an adsorption method using an absorbent is generally used the most [6].

Carbon materials such as activated carbon (AC) have many advantages, such as high surface area, thermal stability, inexpensiveness, and renewability, and are therefore used as major adsorbents [5,7]. In addition, various metals have been supported on carbon materials and used to improve adsorption properties and effects [8]. Silver (Ag) is used widely because it improves the adsorption efficiency and has a sterilizing effect [9]. It is 
known that metal silver $\left(\mathrm{Ag}^{0}\right)$ and silver ion $\left(\mathrm{Ag}^{+}\right)$supported on carbon materials form catalytically, oxidize for some organic compounds, or increase the oxidation potential to improve adsorption capacity $[7,10]$.

The sol-gel method has been mainly used as a method of placing supporting metals on carbon materials. On the other hand, the liquid phase plasma (LPP) method has attracted recent attention [11,12]. The LPP process is a kind of cold plasma process in which plasma is generated by applying a high voltage to an electrode installed in a liquid $[13,14]$. Wastewater treatment, hydrogen production, nanoparticle synthesis, and the fabrication of various composites can be prepared using various radicals and electrons in the plasma field formed in the reaction aqueous solution $[15,16]$. The LPP method is easy to operate and can be prepared in a single step. In addition, it is an eco-friendly process because it does not generate secondary waste $[17,18]$.

In this study, activated carbon fiber $(\mathrm{ACF})$ was prepared using high-density polyethylene fiber as a raw material. Ag/ACF composite was synthesized by precipitating $\mathrm{Ag}$ nanoparticles in the prepared ACF using the LPP method. The acetaldehyde adsorption experiment was performed using $\mathrm{Ag} / \mathrm{ACF}$ composite as an adsorbent, and the pure $\mathrm{ACF}$ and adsorption performance were compared and evaluated.

\section{Materials and Methods}

\subsection{Materials}

In this study, HDPE fiber was prepared by melt spinning of high-density polyethylene (HDPE, 2700 J, Melt index $7.0 \mathrm{~g} / 10 \mathrm{~min}$, Density $0.949 \mathrm{~g} / \mathrm{cm}^{3}$, Lotte chemical Co., Seoul, Korea). ACF prepared by sulfur crosslinking, carbonization, and steam activation of HDPE fiber was used as a support. Sulfuric acid (98\%, 7683-4100, DaeJung Chemical \& Metal Co., Ltd., Gyeonggi-Do, Korea) was used as a crosslinking agent of HDPE fiber. Silver nitrate $\left(\mathrm{AgNO}_{3}\right.$, Sigma-Aldrich, St. Louis, MO, USA) was used as a precursor of silver particles precipitated in ACF. Deionized water (DaeJung Chemical \& Metal Co., Ltd., Gyeonggi-Do, Korea) with an electrical conductivity of 2 siemens or less was used to prepare the LPP aqueous reaction solution. All chemicals were used as received.

\subsection{Preparation of Aactivated Ccarbon Fiber}

Figure 1 shows the process of preparing ACF using HDPE fiber. The HDPE fiber was subjected to pre-crosslinking treatment through electron beam irradiation (EBI); the irradiated electron energy was $2.5 \mathrm{MeV}$, and the irradiation dose of the E-beam was $1000 \mathrm{kGy}$. A crosslink structure was formed by dipping $8 \mathrm{~g}$ of EBI-treated HDPE fiber in $600 \mathrm{~mL}$ of sulfuric acid at $160{ }^{\circ} \mathrm{C}$ for $60 \mathrm{~min}$. Crosslinked HDPE fibers were washed with distilled water and dried in a vacuum oven at $70^{\circ} \mathrm{C}$ for $24 \mathrm{~h}$. The dried HDPE fiber was carbonized at $900^{\circ} \mathrm{C}$ using a self-made alumina tubular furnace $(1000 \mathrm{~mm}$ long and $100 \mathrm{~mm}$ in diameter). Carbonization was carried out for $60 \mathrm{~min}$ using nitrogen gas $(10 \mathrm{~mL} / \mathrm{min})$ being supplied. Thereafter, the inlet gas was changed to water vapor $(0.5 \mathrm{~mL} / \mathrm{min})$ to perform steam activation for $1 \mathrm{~h}$, and after the activation reaction was completed, nitrogen gas $(300 \mathrm{~mL} / \mathrm{min})$ was purged and cooled. 




Figure 1. Preparing process diagram of activated carbon fiber using high-density polyethylene fiber.

\subsection{Preparation of Silver Nanoparticle Precipitated ACF}

Figure 2 shows the LPP device (Nano Technology Co., Ltd., Daejeon, Korea) used in this study to prepare silver nanoparticle precipitated ACF (Ag/ACF composite). Electrical power was supplied to the tungsten electrodes installed in the center of the quartz reactor by using the power supply on the upper left. At this time, the pulse width was $5 \mu \mathrm{s}$, the applied voltage was $250 \mathrm{~V}$, and the frequency was operated under operating conditions of $30 \mathrm{kHz}$. The LPP reactor was manufactured in a double tube type, and in order to prevent the temperature increase due to heat generated by plasma generation, cooling water was circulated in the outer channel of the reactor to keep the temperature of the reactant solution constant at $15^{\circ} \mathrm{C}$.

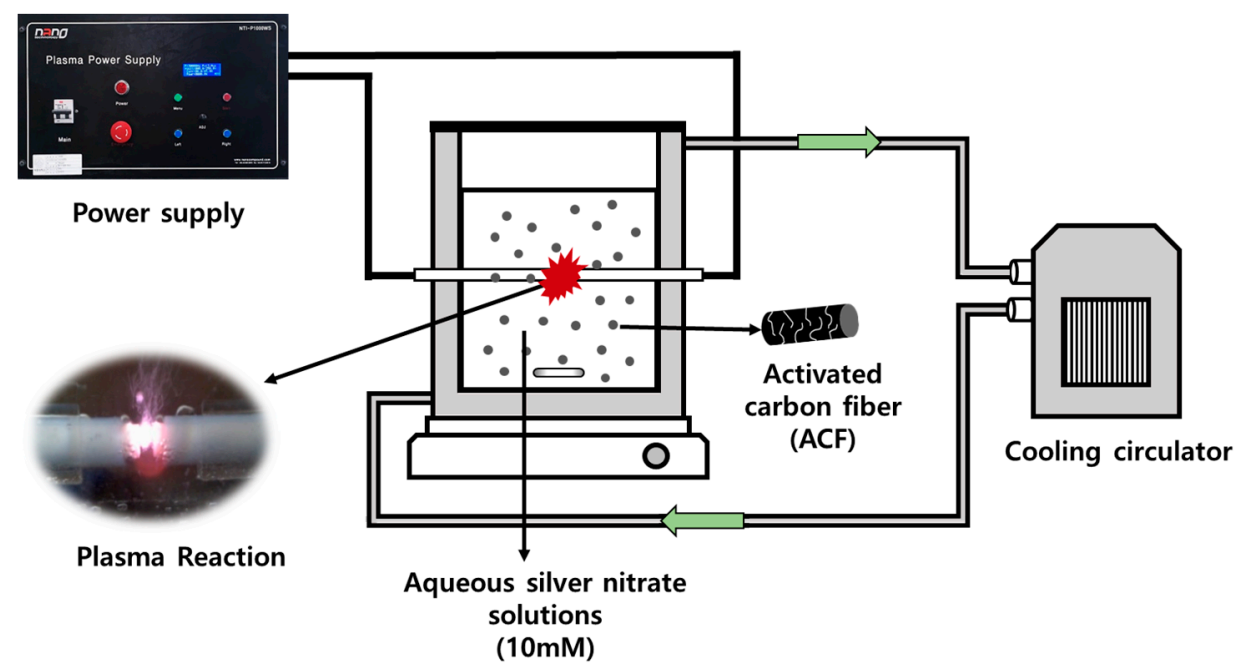

Figure 2. Schematic diagram of LPP method for preparation of Ag particle-precipitated ACF.

The Ag/ACF composite preparation process using the LPP method was performed in the following order [14,18]. The detailed configuration and specifications of the LPP system used in this experiment are described elsewhere. Since ACF prepared by the method shown in Figure 1 is difficult to disperse in the LPP reactant aqueous solution, it was pulverized to a small size using ball milling and dispersed in the solution. After ball milling ACF composite to a powder for $5 \mathrm{~min}, 0.5 \mathrm{~g}$ was mixed with $250 \mathrm{~mL}$ of deionized water. $\mathrm{AgNO}_{3}$, a Ag precursor, was added to the ACF-dispersed reactant aqueous solution at a certain 
concentration (5 15 $\mathrm{mM})$ and stirred until completely dissolved. After transferring the prepared reactant solution to the LPP reactor, the LPP reaction was performed by supplying power to the tungsten electrodes fixed in the center of the reactor using a power supply. After the LPP reaction, the solid was centrifuged, followed by washing and filtration to obtain the $\mathrm{Ag} / \mathrm{ACF}$ composite. The collected $\mathrm{Ag} / \mathrm{ACF}$ composite was vacuum dried at $80^{\circ} \mathrm{C}$ for $24 \mathrm{~h}$ to remove moisture. The number written on the back of the prepared $\mathrm{Ag} / \mathrm{ACF}$ composite means the concentration of $\mathrm{AgNO}_{3}$ added to the reactant aqueous solution. For example, $\mathrm{Ag} / \mathrm{ACF}-15$ is $\mathrm{Ag} / \mathrm{ACF}$ prepared by adding $\mathrm{AgNO}_{3}$ at a concentration of $15 \mathrm{mM}$.

\subsection{Acetaldehyde Adsorption Experiment}

For the acetaldehyde adsorption experiment, a special preparation was used in which acetaldehyde was added to nitrogen gas, a dilution gas, to make a concentration of $20 \mathrm{ppm}$. A self-contained fix-bed adsorption system was used for the acetaldehyde adsorption experiment, and the adsorbent (ACF and Ag/ACF composite) was placed in the center of a quartz tube (700 $\mathrm{mm}$ length, $25.4 \mathrm{~mm}$ diameter). The amount of adsorbent used was added constantly at $0.3 \mathrm{~g}$. The flow rate and reaction temperature of the acetaldehyde reaction gas were kept constant at $400 \mathrm{~mL} / \mathrm{min}$ and $20^{\circ} \mathrm{C}$, respectively. After collecting a $100 \mathrm{~mL}$ sample using a gas sampling pump (GV-100, GASTEC Corp., Kanagawa, Japan) of the reaction gas that has passed through the adsorption tube filled with adsorbent, the detector tube (No. 92L, GASTEC Corp., Kanagawa, Japan) was used to measure the acetaldehyde concentration.

\subsection{Characterization of $\mathrm{Ag} / \mathrm{ACF}$ Composite}

The morphology and chemical composition of the Ag/ACF composite prepared using the LPP method were measured by field-emission scanning electron microscopy FE-SEM (JSM-7100F, JEOL Ltd., Tokyo, Japan) and energy-dispersive X-ray spectrometry (EDS). X-ray diffraction (X'Port PRO, PANalytical, Almelo, The Netherlands) was conducted to examine the crystallinity. The physicochemical properties of the Ag/ACF composite were measured by X-photoelectron spectroscopy (Multilab 2000 system, Thermo Fisher Scientific, Waltham, MA, USA) with non-monochromatic $\mathrm{Al} \mathrm{Ka}$ radiation $(1486.6 \mathrm{eV})$, and the $\mathrm{N}_{2}$ isotherm curve, surface area, and pore size distribution of $\mathrm{ACF}$ and $\mathrm{Ag} / \mathrm{ACF}$ composite were measured using BELSORP-Max (BEL Japan, Tokyo, Japan).

\section{Results}

Figure 3 shows FE-SEM images, and the results of EDX analysis of Ag/ACF-15 composite prepared using the LPP method. Figure 3a shows the spectrum by EDS attached to the FE-SEM. The peaks at $0.25 \mathrm{keV}$ and $0.53 \mathrm{keV}$ were assigned to carbon $(\mathrm{C} \mathrm{K} \alpha)$ and oxygen $(\mathrm{O} \mathrm{K} \alpha)$. The peak at $2.98 \mathrm{keV}$ was due to silver $(\mathrm{Ag} \mathrm{L} \alpha)$. The composition of the $\mathrm{Ag} / \mathrm{ACF}$ composite was $93.63 \mathrm{At} . \%, 4.83 \mathrm{At} . \%$, and $1.54 \mathrm{At} . \%$ of carbon, oxygen, and silver, respectively. Figure $3 \mathrm{~b}$ presents an FE-SEM real image of the Ag/ACF-15 composite. Ag particles were observed on the surface of ACF with a size of $200 \mathrm{~nm}$ to $500 \mathrm{~nm}$. In the plasma field generated in the aqueous reaction solution, $\mathrm{H}_{2} \mathrm{O}_{2}$ is produced by active species, such as $\mathrm{OH}$ radicals. The $\mathrm{Ag}$ ions dissociated from the precursor and present in the aqueous reaction solution were reduced through the following reaction, converted to Ag particles, and precipitated on the ACF surface [19].

$$
2 \mathrm{Ag}^{+}+\mathrm{H}_{2} \mathrm{O}_{2} \rightarrow 2 \mathrm{Ag} \downarrow+2 \mathrm{H}^{+}+\mathrm{O}_{2}
$$

Figure 3c,d show the mapping images of $\mathrm{C}$ and $\mathrm{Ag}$ on the Ag/ACF-15 composite surface. In the case of Figure 3c, the carbon element exists in the same way as the ACF form, and the silver element in Figure $3 \mathrm{~d}$ was detected at the same location as the Ag particles in Figure $3 b$. 

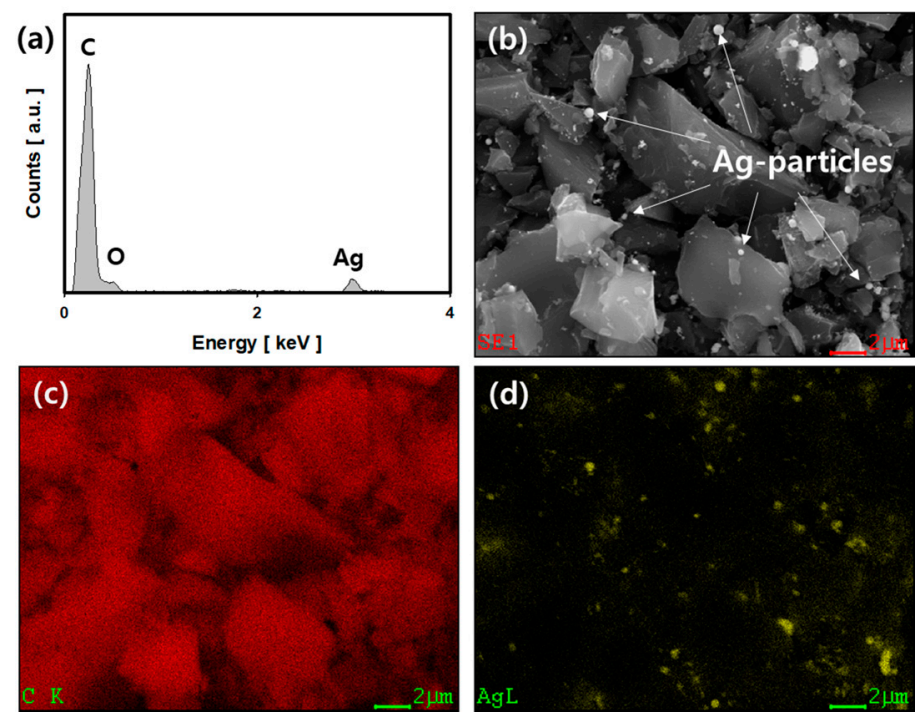

Figure 3. Analysis results of FE-SEM and EDS of Ag/ ACF-15 composite prepared by the LPP method: (a) EDS spectrum, (b) FE-SEM real image and (c) carbon element mapping image, and (d) Ag element mapping image.

Table 1 presents the atomic compositions of ACF and Ag/ACF composites calculated from the results of EDS analysis attached to FE-SEM. ACF consisted of the carbon element (C) and oxygen element $(\mathrm{O})$ at 96.57 At.\% and 3.43 At.\% ratios, respectively. Ag/ACF compositions prepared using the LPP method showed that the Ag element increased in proportion to the injected $\mathrm{Ag}$ precursor concentration and, accordingly, the carbon element decreased. On the other hand, as the content of the Ag element increased, the At.\% of oxygen also showed a tendency to increase.

Table 1. Atomic composition of ACF prepared from high-density polyethylene fiber and Ag/ACF composites prepared by LPP method.

\begin{tabular}{ccccc}
\hline \multirow{2}{*}{ Sample } & \multirow{2}{*}{ Initial Conc. of Precursor (mM) } & \multicolumn{3}{c}{ Atomic Composition (\%) } \\
\cline { 3 - 4 } & & $\mathbf{C}$ & $\mathbf{O}$ & $\mathbf{A g}$ \\
\hline $\mathrm{ACF}$ & 0 & 96.57 & 3.43 & 0.00 \\
$\mathrm{Ag} / \mathrm{ACF}-10$ & 10 & 93.63 & 4.84 & 1.53 \\
$\mathrm{Ag} / \mathrm{ACF}-15$ & 15 & 92.11 & 5.42 & 2.47 \\
$\mathrm{Ag} / \mathrm{ACF}-20$ & 20 & 90.92 & 5.81 & 3.27 \\
\hline
\end{tabular}

Figure 4 shows the XRD pattern of ACF and the Ag/ACF-15 composite. In the ACF in Figure 4 , diffraction lines were observed at $21.3^{\circ}$ and $43.5^{\circ}$ at $2 \theta$, which were assigned to the $C(002)$ and (01) planes, respectively. With graphite, the diffraction line of the C (002) plane is generally observed at $25^{\circ} 2 \theta$, but the ACF used in this study shifted to a low $2 \theta$. This means that the ACF used in this experiment has a wide space between the carbon lattice [20]. In the case of the Ag/ ACF-15 composite shown above, four diffraction lines were also observed along with the $C(002)$ and (10) planes shown in ACF. The strong peak at $38.1^{\circ} 2 \theta$ is the diffraction line due to the metallic $\mathrm{Ag}$ (111) plane and the $\mathrm{Ag}_{2} \mathrm{O}$ (200) plane. The diffraction lines at $44.2^{\circ}, 64.2^{\circ}$, and $77.4^{\circ} 2 \theta$ were assigned to the $\mathrm{Ag}(200), \mathrm{Ag}$ (220), and Ag (311) planes [21]. The Ag particles precipitated by the LPP method were a mixture of metallic silver $\left(\mathrm{Ag}^{0}\right)$ and silver oxide $\left(\mathrm{Ag}_{2} \mathrm{O}\right)$, which was consistent with the XRD pattern of Figure 4. 


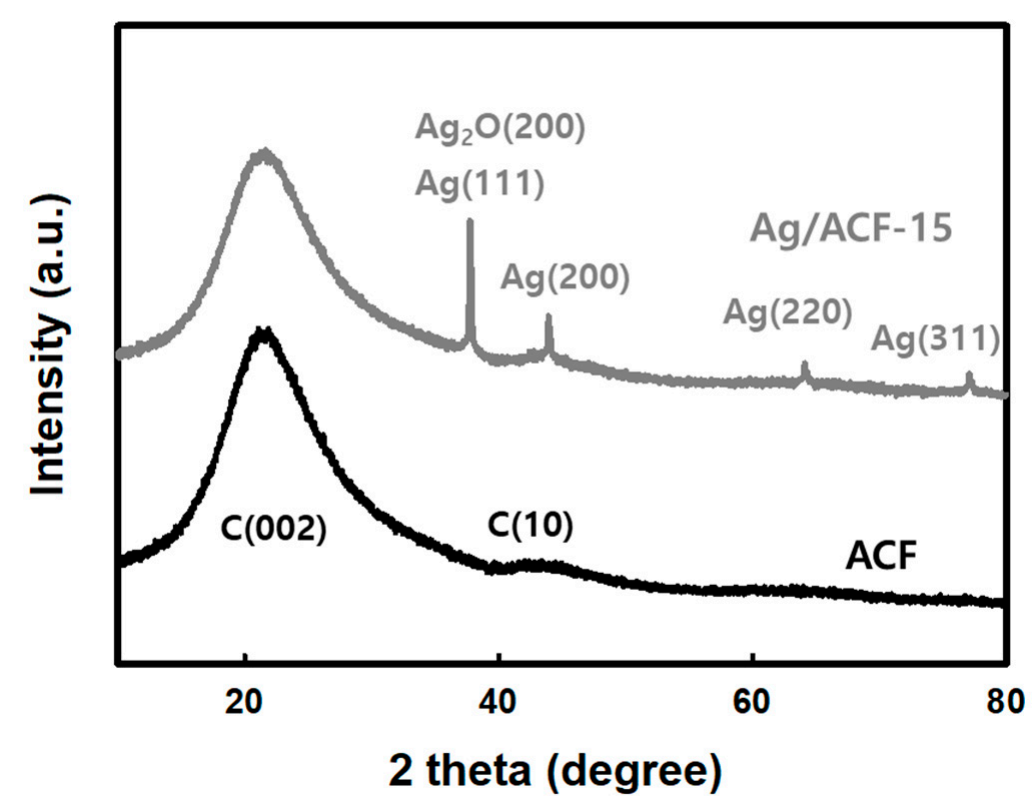

Figure 4. X-ray diffraction patterns of ACF and Ag/ACF-15 composite.

Figure 5 shows the C1s, O1s, Ag3d, and Ag MNN XPS spectrum of the Ag/ACF-15 composite. In Figure 5a, C1s photoelectron line was fitted to three contributions. The peak at binding energy (BE) $284.6 \mathrm{eV}$ was due to the graphite carbon $\mathrm{C}-\mathrm{C}$ bond, the peak at $\mathrm{BE}$ $286.2 \mathrm{eV}$ was due to the $\mathrm{C}-\mathrm{O}$ bond, and the peak at $\mathrm{BE} 287.1 \mathrm{eV}$ was due to the carbon of the $\mathrm{C}=\mathrm{O}$ bond $[22,23]$. In the O1s region of Figure $5 b$, three fitted photoelectron lines were observed, and the weak binding energy peak of $529.8 \mathrm{eV}$ was due to a $\mathrm{Ag}-\mathrm{O}$ bond. The results in Figure 4 confirmed that the Ag precipitated on the ACF surface was in the form of metallic $\mathrm{Ag}$ and $\mathrm{Ag}_{2} \mathrm{O}$ crystals. Therefore, the peak is due to the $\mathrm{Ag}-\mathrm{O}$ bond of $\mathrm{Ag}_{2} \mathrm{O}$ [24]. The peaks at $531.2 \mathrm{eV}$ and $532.2 \mathrm{eV}$ were assigned to oxygen bonded to the carbon of ACF-15 composite, such as $\mathrm{C}=\mathrm{O}$ and $\mathrm{C}-\mathrm{OH}$ or $\mathrm{C}-\mathrm{O}-\mathrm{C}$ bonds [25]. Figure $5 \mathrm{c}$ is the XPS result for the $\mathrm{Ag} 3 \mathrm{~d}$ region, and two doublet-fitted photoelectron lines were observed. The peaks observed at $\mathrm{BE} 367.6 \mathrm{eV}$ and $373.6 \mathrm{eV}$ were generated by $\mathrm{Ag}_{2} \mathrm{O}$ with an oxidation state of +1 , and the peaks generated at $\mathrm{BE} 368.3 \mathrm{eV}$ and $374.3 \mathrm{eV}$ were peaks by metallic silver $\left(\mathrm{Ag}^{0}\right)$ [26-28]. In addition, the spin orbital splitting between $\mathrm{Ag}_{3} \mathrm{~d}_{5 / 2}$ and $\mathrm{Ag}_{3} \mathrm{~d}_{3 / 2}$ of $\mathrm{Ag}_{2} \mathrm{O}$ and metallic silver was maintained at $6.0 \mathrm{eV}$ [28]. Figure $5 \mathrm{~d}$ is a $\mathrm{Ag} \mathrm{MNN}$ spectrum, and a weak intensity peak was observed. Kinetic energy (KE) peaks at $350.2 \mathrm{eV}$ and $352.2 \mathrm{eV}$ are peaks by $\mathrm{Ag} \mathrm{M}_{5} \mathrm{~N}_{45} \mathrm{~N}_{45}$ of $\mathrm{Ag}^{+1}$ and $\mathrm{Ag}^{0}$. Auger parameter (AP) was calculated using $\mathrm{BE}$ of Ag3d $\mathrm{d}_{5 / 2}$ and $\mathrm{KE}$ of $\mathrm{Ag} \mathrm{MNN}\left(\mathrm{Ag} \mathrm{M}_{5} \mathrm{~N}_{45} \mathrm{~N}_{45}\right.$ and $\left.\mathrm{Ag} \mathrm{M}_{4} \mathrm{~N}_{45} \mathrm{~N}_{45}\right)$, and AP of Metallic Ag was $720.5 \mathrm{eV}\left(\mathrm{Ag} 3 \mathrm{~d}_{5 / 2}-\mathrm{Ag} \mathrm{M} \mathrm{M}_{5} \mathrm{~N}_{45} \mathrm{~N}_{45}\right)$ and $726.4 \mathrm{eV}\left(\mathrm{Ag}_{3} \mathrm{~d}_{5 / 2}-\mathrm{Ag} \mathrm{M}_{4} \mathrm{~N}_{45} \mathrm{~N}_{45}\right)$. The AP of $\mathrm{Ag}^{+1}$ was calculated to be $717.8 \mathrm{eV}\left(\mathrm{Ag} 3 \mathrm{~d}_{5 / 2}-\mathrm{Ag} \mathrm{M}_{5} \mathrm{~N}_{45} \mathrm{~N}_{45}\right)$ and $723.7 \mathrm{eV}\left(\mathrm{Ag} 3 \mathrm{~d}_{5 / 2}-\mathrm{Ag}\right.$ $\mathrm{M}_{4} \mathrm{~N}_{45} \mathrm{~N}_{45}$ ), and it was confirmed that it was due to silver ion of $\mathrm{Ag}_{2} \mathrm{O}$ [28]. Overall, XPS showed that the Ag particles precipitated by LPP were a mixture of metallic silver and silver oxide, which is consistent with the XRD pattern in Figure 4. 

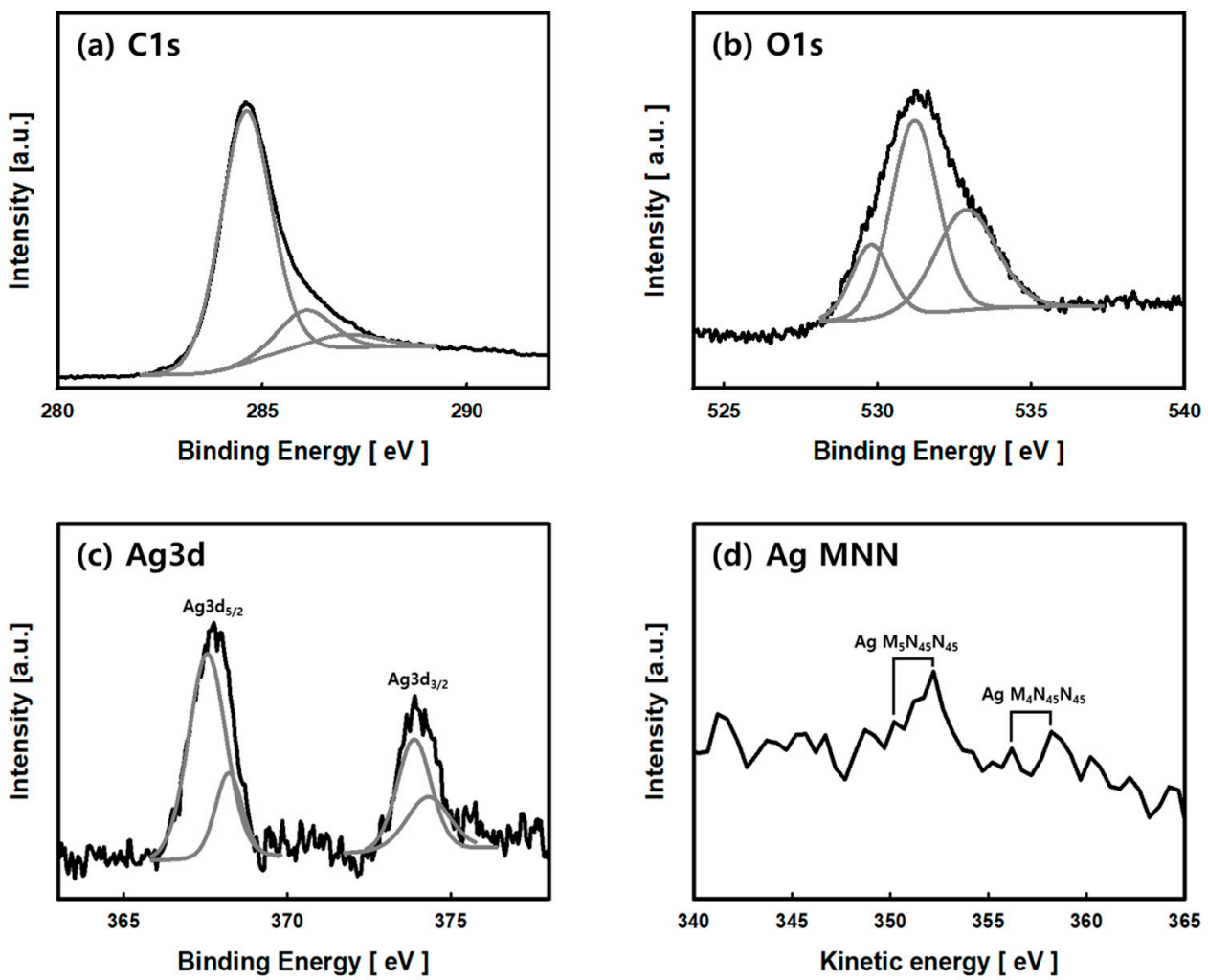

Figure 5. XPS spectra of the C1s region (a), O1s region (b), Ag3d region (c), and Ag NMM (d) of Ag/ACF-15 composite prepared by the LPP method.

Figure 6a shows the nitrogen adsorption-desorption isotherm curves of ACF and the Ag/ACF-15 composite measured under $77 \mathrm{~K} / \mathrm{N}_{2}$ conditions. Both ACF and the Ag/ACF15 composite showed a mixed form of a type-I and type-IV isotherm profile. In the case of $\mathrm{ACF}$, a small H4 hysteresis loop was observed in the $0.5 \sim 0.8 \mathrm{P} / \mathrm{P}_{0}$ range. The Ag/ACF15 composite curve showed a somewhat lower $\mathrm{N}_{2}$ adsorption behavior than the ACF curve, and the hysteresis loop of the mesopore section that appeared in ACF was reduced significantly. Ag particles precipitated by the LPP method affected the surface area. The surface area of Ag/ACF-15 composite measured by the Brunauer-Emmett-Teller (BET) method was $1264 \mathrm{~m}^{2} / \mathrm{g}$, which was lower than that of the ACF (1462 $\left.\mathrm{m}^{2} / \mathrm{g}\right)$. Ag particles precipitated by the LPP reaction had a blocking effect on the micro and mesopore structure of ACF, which reduced the surface area [29]. Figure $6 b$ is the pore size distribution (PSD) of ACF and the Ag/ACF-15 composite measured using the Barrett-Joyner-Halenda (BJH) method. ACF mainly had a mesopore structure with a size of 2 to $50 \mathrm{~nm}$. In the case of Ag/ACF-15, in which Ag particles were precipitated on the surface of the ACF by the LPP method, it was shown that the pores corresponding to the size of $2 \sim 30 \mathrm{~nm}$ were reduced. 

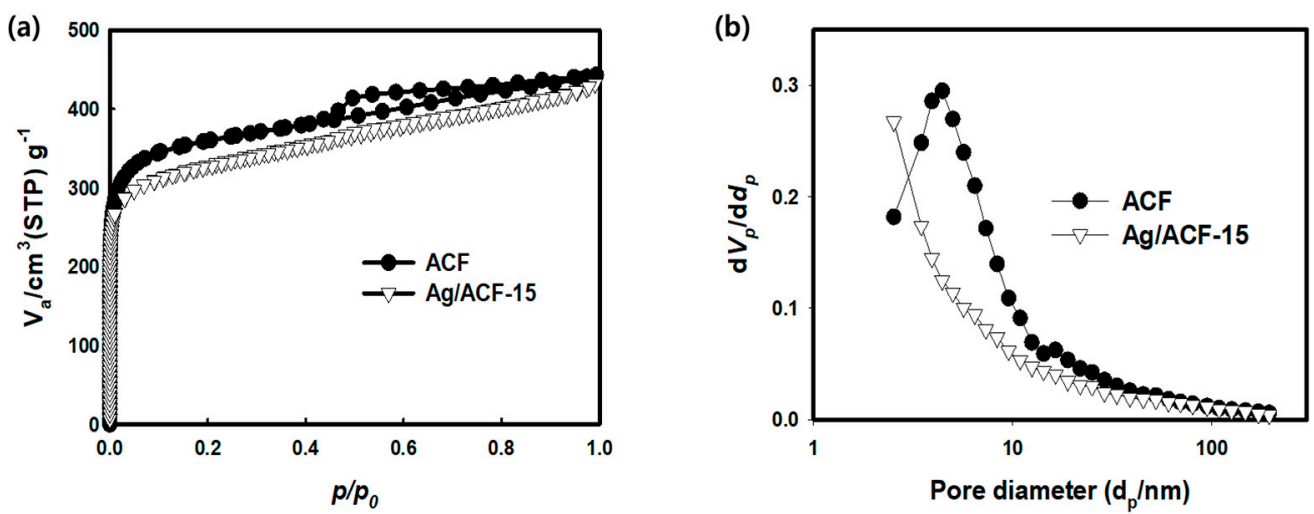

Figure 6. Adsorption-desorption isotherm curves (a) and pore size distribution (b) of ACF and Ag/ACF-15 composite.

Table 2 shows pore characteristics such as specific surface area, total pore volume, micropore volume, mesoporous volume, mesopore ratio, and pore diameter obtained through the BET and BJH method. The surface area, pore volume and mesopore ratio of $\mathrm{Ag} / \mathrm{ACF}$ composites showed lower values than those of $\mathrm{ACF}$, indicating that they were inversely proportional to the amount of Ag precipitated on the ACF surface. It is presumed that this is because the blocking effect of ACF on the pore inlet increases due to the increase in the Ag content precipitated through the LPP process. The average pore diameter of $\mathrm{Ag} / \mathrm{ACF}$ composite was overall lower than that of ACF.

Table 2. Textural properties of ACF and Ag/ACF composites.

\begin{tabular}{|c|c|c|c|c|c|c|}
\hline Sample & $\begin{array}{l}S_{B E T} 1 \\
\left(\mathrm{~m}^{2} / g\right)\end{array}$ & $\begin{array}{l}V_{\text {Total }}^{2} \\
\left(\mathrm{~cm}^{3} / \mathrm{g}\right)\end{array}$ & $\begin{array}{l}V_{\text {Microo }}^{3} \\
\left(\mathrm{~cm}^{3} / \mathrm{g}\right)\end{array}$ & $\begin{array}{l}V_{\text {Meso }} 4 \\
\left(\mathrm{~cm}^{3} / \mathrm{g}\right)\end{array}$ & $\begin{array}{c}\text { Mesopore Ratio } \\
(\%)\end{array}$ & $\begin{array}{c}\text { Pore Diameter } \\
(\mathrm{nm})\end{array}$ \\
\hline $\mathrm{ACF}$ & 1462 & 0.6844 & 0.4856 & 0.1988 & 29.05 & 4.42 \\
\hline $\mathrm{Ag} / \mathrm{ACF}-10$ & 1316 & 0.6438 & 0.4771 & 0.1667 & 25.89 & 3.96 \\
\hline Ag/ACF-15 & 1264 & 0.6296 & 0.4734 & 0.1562 & 24.80 & 4.03 \\
\hline $\mathrm{Ag} / \mathrm{ACF}-20$ & 1208 & 0.6127 & 0.4702 & 0.1425 & 23.52 & 4.02 \\
\hline
\end{tabular}

${ }^{1} \mathrm{~S}_{\mathrm{BET}}$ : Specific surface area; BET method, ${ }^{2} \mathrm{~V}_{\text {Total }}$ : Total pore volume; $\mathrm{P} / \mathrm{P}_{\mathrm{o}}=0.990 .{ }^{3} \mathrm{~V}_{\text {Micro }}$ : Micropore volume $\mathrm{t}$-plot method, ${ }^{4} \mathrm{~V}_{\text {Meso }}$ : Mesopore volume; $\mathrm{V}_{\text {Tota }} \mathrm{l}-\mathrm{V}_{\text {Meso }} .{ }^{5}$ Mesorpore ratio: $\left(\mathrm{V}_{\text {meso }} / \mathrm{V}_{\text {Total }}\right) \times 100 .{ }^{6}$ Pore diameter: BJH method.

Figure 7 shows the results of changes in AA concentration at the outlet of the adsorption reactor for each reaction time obtained from an AA adsorption experiment using $\mathrm{ACF}$ and $\mathrm{Ag} / \mathrm{ACF}$ composites as an adsorbent. In both $\mathrm{ACF}$ and $\mathrm{Ag} / \mathrm{ACF}$ composites, the concentration of AA at the outlet of the adsorption reactor increased slowly at the beginning of the reaction, but showed a tendency to increase rapidly after breakthrough In addition, $\mathrm{Ag}-\mathrm{ACF}$ composites showed higher $\mathrm{AA}$ adsorption performance compared to ACF. Ag precipitated on the surface of ACF decreased the surface area and pore volume, but improved the adsorption properties of acetaldehyde. It can be seen that these results are consistent with Table 2. 


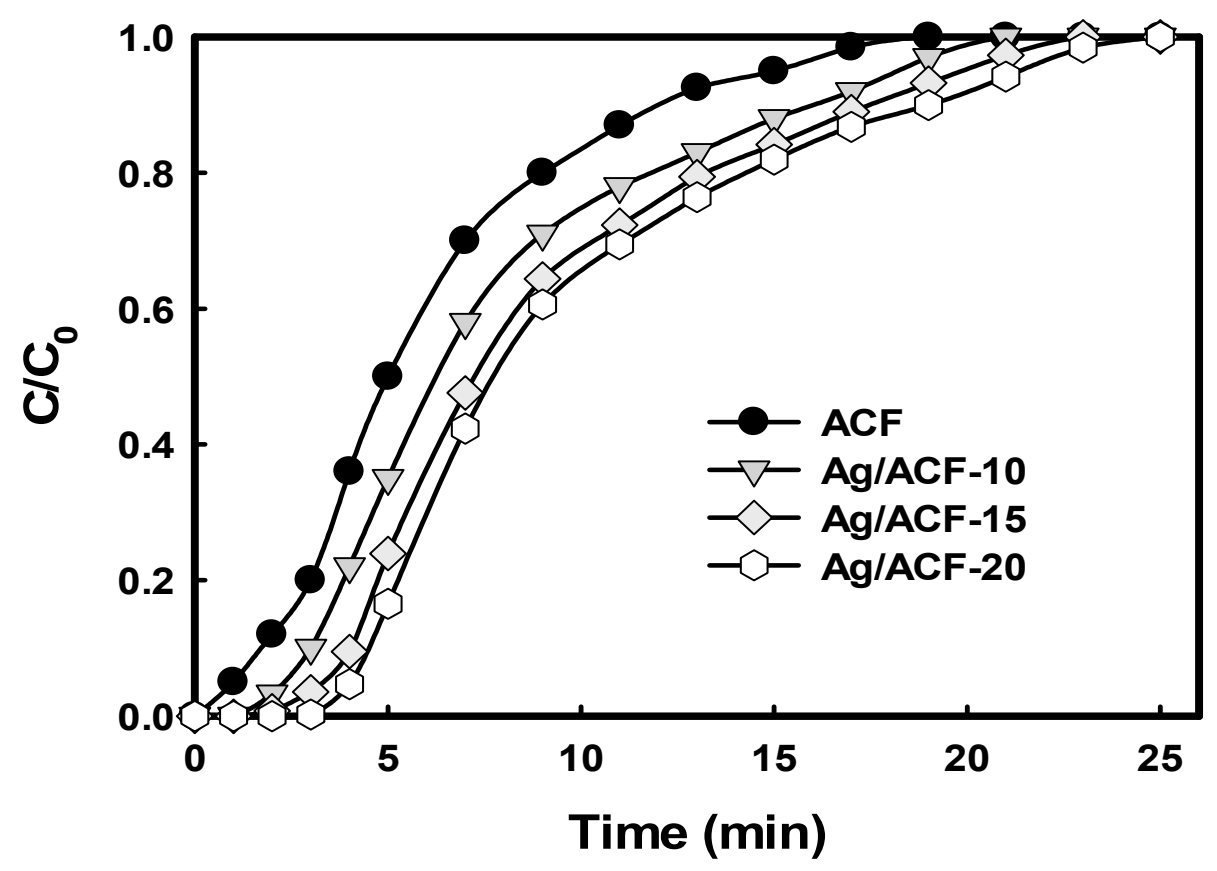

Figure 7. Acetaldehyde adsorption breakthrough curves of ACF and Ag/ACF composites.

Figure 8 and Table 3 show the AA adsorption capacity and column efficiency parameters obtained using the results of Figure 5. The gas flow rate $\mathrm{Q}$ at which AA was diluted was $400 \mathrm{~mL} / \mathrm{min}$, and the initial concentration of AA $\left(\mathrm{C}_{0}\right)$ was $20 \mathrm{mg} / \mathrm{L}$. The absorbent mass $(m)$ was $0.3 \mathrm{~g}$, and the height of absorbent $(Z)$ was $5.0 \mathrm{~mm}$. The breakthrough time $\left(t_{b}, C / C_{0}=0.05\right)$ and exhaustion time $\left(t_{e}, C / C_{0}=1.0\right)$ of Ag/ACF composites were obtained from 2.4 to $4.1 \mathrm{~min}$ and 21.0 to $25.0 \mathrm{~min}$. Additionally, it can be seen that these values are higher than the $t_{b}(1.0 \mathrm{~min})$ and $t_{e}(19.0 \mathrm{~min})$ of ACF. At the breakthrough time and exhaustion time of ACF, the adsorption amount of AA was calculated to be $26.0 \mathrm{mg} / \mathrm{g}$ and $161.6 \mathrm{mg} / \mathrm{g}$, respectively. The AA adsorption amounts of Ag/ACF composites prepared by the LPP process was $63.1 \sim 108.6 \mathrm{mg} / \mathrm{g}$ in $\mathrm{t}_{\mathrm{b}}$ and $207.5 \sim 258.7 \mathrm{mg} / \mathrm{g}$ in $\mathrm{t}_{\mathrm{e}}$. Ag/ACF composites increased 2.4 4.2 $\left(\mathrm{t}_{\mathrm{b}}\right)$ times and 1.3 1.6 $\left(\mathrm{t}_{\mathrm{e}}\right)$ times compared to ACF, indicating that the adsorption performance of AA by Ag particles was improved at breakthrough and exhaustion time. In addition, the height of the mass transfer zone was also reduced by 17 to $31 \%$ in Ag/ACF composites compared to ACF, suggesting that the fixed bed column due to low mass transfer resistance can be used more efficiently [30]. It was found that Ag particles precipitated on the surface of the ACF by the LPP reaction improved the AA adsorption ability, and the amount of Ag particles acted as a major influence factor on the adsorption performance improvement. This is presumed to be due to the high adsorption affinity between the Ag particles on the ACF surface and the carbonyl group of AA [31,32]. Baur et al. (2015) improved the adsorption performance of AA by supporting metal oxides such as $\mathrm{La}_{2} \mathrm{O}_{3}, \mathrm{CaO}, \mathrm{MgO}, \mathrm{ZnO}, \mathrm{Al}_{2} \mathrm{O}_{3}$, and $\mathrm{TiO}_{2}$ on the surface of $\mathrm{ACF}$, and $\mathrm{MgO}$ and $\mathrm{ZnO}$ increased the AA adsorption capacity by about 4 to 5 times [31]. In this study, the $\mathrm{Ag} / \mathrm{ACF}$ composites prepared by the LPP method also showed an increase in the amount of AA adsorption at the breakthrough time (tb), similar to the results of the above study. 
(a)



(b)



Figure 8. Breakthrough adsorption capacity $\left(\mathrm{Q}_{b}\right)$ and exhaustion adsorption capacity $\left(\mathrm{Q}_{\mathrm{e}}\right)$ obtained from AA adsorption breakthrough curve (a) and relative adsorption capacity versus concentration of silver precursor (b).

Table 3. Comparison of efficiency parameters for acetaldehyde adsorption.

\begin{tabular}{|c|c|c|c|c|c|c|c|}
\hline Sample & $t_{b}^{1}(\min )$ & $t_{e}^{2}(\min )$ & $\mathrm{Q}_{\mathrm{b}}{ }^{3}(\mathrm{mg} / \mathrm{g})$ & $\mathrm{Q}_{\mathrm{e}}{ }^{4}(\mathrm{mg} / \mathrm{g})$ & $\% \mathbf{R}_{b}{ }^{5}$ & $\% R_{e}{ }^{6}$ & $\mathrm{~h}_{-} \mathrm{MTZ}^{7}(\mathrm{~cm})$ \\
\hline $\mathrm{ACF}$ & 1.0 & 19.0 & 26.0 & 161.6 & 97.5 & 31.9 & 0.42 \\
\hline $\mathrm{Ag} / \mathrm{ACF}-10$ & 2.4 & 21.0 & 63.1 & 2 & 98.6 & 37.1 & 0.35 \\
\hline Ag/ACF-15 & 3.5 & 23.0 & 92.1 & 23 & 98.7 & 38.9 & 0.31 \\
\hline $\mathrm{Ag} / \mathrm{ACF}-20$ & 4.1 & 25.0 & 108.6 & 258.7 & 99.4 & 38.8 & 0.29 \\
\hline \multicolumn{8}{|c|}{$\begin{array}{l}\text { Breakthrough time, }{ }^{2} \text { Exhaustion time. }{ }^{3} \text { Breakthrough adsorption capacity: } \mathrm{Q}_{\mathrm{b}}=\frac{\mathrm{C}_{0} \mathrm{Q}}{\mathrm{m}} \int_{0}^{\mathrm{t}_{\mathrm{b}}}\left(1-\frac{\mathrm{C}}{\mathrm{C}_{0}}\right) \mathrm{dt} \\
\text { Exhaustion adsorption capacity: } \mathrm{Q}_{\mathrm{e}}=\frac{\mathrm{C}_{0} \mathrm{Q}}{\mathrm{m}} \int_{0}^{\infty}\left(1-\frac{\mathrm{C}}{\mathrm{C}_{0}}\right) \mathrm{dt} \text {, where } \mathrm{m} \text { is the adsorbent mass }(\mathrm{g}) \text { and } \mathrm{t} \text { is the } \\
\text { perating time. }{ }^{5} \text { Removal percentages of breakthrough: } \% \mathrm{R}_{\mathrm{b}}=\left(\frac{\mathrm{q}_{\mathrm{b}} \mathrm{m}}{\mathrm{C}_{0} \mathrm{Qt}_{\mathrm{b}}}\right) \times 100 .{ }^{6} \text { Removal percentages of } \\
\text { xhaustion: } \% \mathrm{R}_{\mathrm{e}}=\left(\frac{\mathrm{q}_{\mathrm{e}} \mathrm{m}}{\mathrm{C}_{0} \mathrm{Q} \mathrm{e}_{\mathrm{e}}}\right) \times 100 .{ }^{7} \text { Height of the mass transfer zone: } \mathrm{h}_{\mathrm{MTZ}}=\left(1-\frac{\mathrm{q}_{\mathrm{b}}}{\mathrm{q}_{\mathrm{e}}}\right) \mathrm{Z} \text {. }\end{array}$} \\
\hline
\end{tabular}

The breakthrough curve showing the dynamic adsorption characteristics between adsorbent-adsorbate systems is used as important information to design an actual fixed bed adsorption column [33]. In this study, Bohart-Adams, Thomas, Yoon-Nelson, DoseResponse, and Clark equations were used to examine the dynamic adsorption characteristics of AA in a fixed bed column [34-38]. Although the above-mentioned equations are mathematically simple and have limited model parameters, they are widely used in fixed-bed column breakthrough curve modeling studies because they show excellent fitting results $[33,39]$. The parameter values of each of the above-mentioned formulas were obtained using the Nelder-Mead method [40]. Table 4 shows the parameter values and correlation coefficient $\left(R^{2}\right)$ values of each equation. Among the formulas used, the Dose-Response model showed the highest correlation coefficient $\left(R^{2}>0.994\right)$ compared to other models, and the fitting for the results in Figure 5 was in the order Dose-Response $>$ Clark $>$ Bohart-Adams $=$ Thomas $=$ Yoon-Nelson. Through the above results, it can be said that the AA adsorption of ACF and Ag/ ACF composites is suitable for the DoseResponse model. It is known that the Dose-Response model describes a system in which diffusion within particles is a rate controlling step, and the adsorbent is composed of two or more components with different reactivity, resulting in an asymmetric breakthrough curve shape [33]. 
Table 4. Breakthrough models used in this study and their calculated parameters.

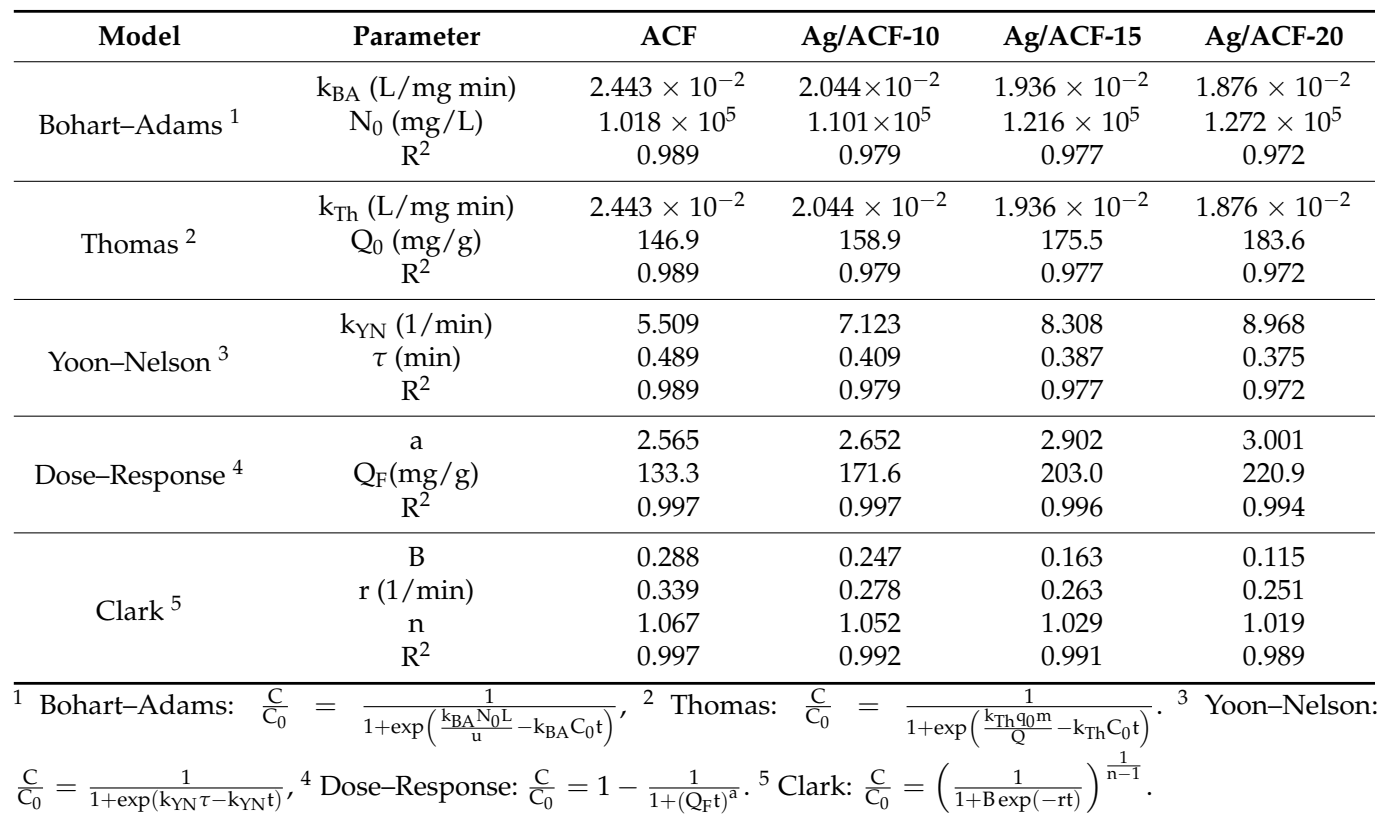

Figure 9 is a graph fitted by applying the Dose-Response model to the results of Figure 7, and satisfactorily fitting the experimental data showing the asymmetric shape of the AA adsorption breakthrough curve for ACF and Ag/ACF composites.

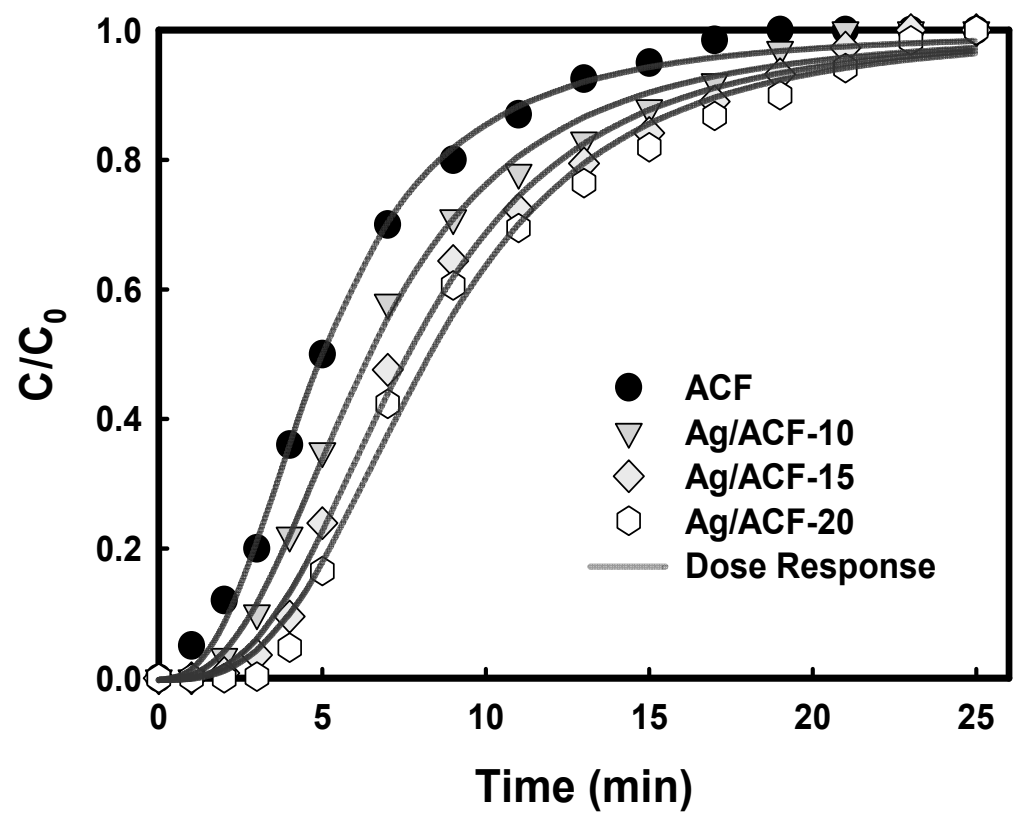

Figure 9. The experimental value and predicted breakthrough curve for AA adsorption based on dose response model.

\section{Conclusions}

Ag particles were precipitated on an ACF surface using the LPP method to prepare a $\mathrm{Ag} / \mathrm{ACF}$ composite. In addition, the prepared $\mathrm{Ag} / \mathrm{ACF}$ composite was applied as an adsorbent, and the efficiency was examined through an adsorption experiment of acetaldehyde. FE-SEM and EDS confirmed that Ag particles were distributed uniformly over the ACF surface. XRD showed that metallic silver $\left(\mathrm{Ag}^{0}\right)$ and silver oxide $\left(\mathrm{Ag}_{2} \mathrm{O}\right)$ precipitated simultaneously on the ACF surface. High-resolution XPS confirmed peaks due to $\mathrm{Ag}_{2} \mathrm{O}$ and $\mathrm{Ag}^{0}$. The surface area of the $\mathrm{Ag} / \mathrm{ACF}$ composite measured by BET was 
$1316 \mathrm{~m}^{2} / \mathrm{g}$, which was lower than that of ACF $\left(1462 \mathrm{~m}^{2} / \mathrm{g}\right)$. Hence, the presence of Ag reduced the surface area by blocking the pores with the Ag particles. Ag precipitated on the surface of ACF decreased the surface area and pore volume but improved the adsorption properties of acetaldehyde. The adsorption affinity between the Ag particles precipitated on the surface of the ACF and the carbonyl group of AA is increased, and it is presumed that the adsorption capacity is improved. The AA adsorption of ACF and Ag/ACF composites performed in this study was suitable for the Dose-Response model, and the experimental data showing the asymmetric shape of the AA adsorption breakthrough curve for ACF and $\mathrm{Ag} / \mathrm{ACF}$ composites were satisfactorily fitted.

Author Contributions: S.-C.J. conceived and designed the experiments; B.-J.K., J.P. and H.L. performed the experiments.; K.-H.A., W.-G.S. and Y.-K.P. contributed to the analysis and the interpretation of data.; B.-J.K. and S.-C.J. wrote the original draft version of paper. All authors have read and agreed to the published version of the manuscript.

Funding: This research was supported by Nano-Material Technology Development Program through the National Research Foundation of Korea (NRF) funded by the Ministry of Science and ICT (NRF2019M3A7B9071501 and NRF-2019M3A7B9071745).

Data Availability Statement: The data presented in this study are available on request from the corresponding author.

Conflicts of Interest: The authors declare no conflict of interest.

\section{References}

1. El-Sayed, Y.; Bandosz, T.J. A Study of Acetaldehyde Adsorption on Activated Carbons. J. Colloid Interface Sci. 2001, $242,44-51$. [CrossRef]

2. Singh, M.; Zhou, N.; Paul, D.K.; Klabunde, K.J. IR spectral evidence of aldol condensation: Acetaldehyde adsorption over TiO 2 surface. J. Catal. 2008, 260, 371-379. [CrossRef]

3. Tabakoff, B.; Anderson, R.A.; Ritzmann, R.F. Brain acetaldehyde after ethanol administration. Biochem. Pharmacol. 1976, 25, 1305-1309. [CrossRef]

4. Dellarco, V.L. A mutagenicity assessment of acetaldehyde. Mutat. Res. Rev. Genet. 1988, 195, 1-20. [CrossRef]

5. Park, S.H.; Yaqub, M.; Lee, S.H.; Lee, W.T. Adsorption of acetaldehyde from air by activated carbon and carbon fibers. Environ. Eng. Res. 2022, 27, 200549. [CrossRef]

6. Yamashita, K.; Noguchi, M.; Mizukoshi, A.; Yanagisawa, Y. Acetaldehyde Removal from Indoor Air through Chemical Absorption Using L-Cysteine. Int. J. Environ. Res. Public Health 2010, 7, 3489-3498. [CrossRef]

7. Rengga, W.D.P.; Chafidz, A.; Sudibandriyo, M.; Nasikin, M.; Abasaeed, A.E. Silver nano-particles deposited on bamboo-based activated carbon for removal of formaldehyde. J. Environ. Chem. Eng. 2017, 5, 1657-1665. [CrossRef]

8. Wang, H.; Jusys, Z.; Behm, R.J. Ethanol and Acetaldehyde Adsorption on a Carbon-Supported Pt Catalyst: A Comparative DEMS Study. Fuel Cells 2004, 4, 113-125. [CrossRef]

9. Wu, G.; Stacchiola, D.; Collins, M.; Tysoe, W.T. The Adsorption and reaction of Acetaldehyde on clean Ag (111). Surf. Rev. Lett. 2000, 7, 271-275. [CrossRef]

10. Chang, S.M.; Hu, S.C.; Shiue, A.; Lee, P.Y.; Leggett, G. Adsorption of silver nano-particles modified activated carbon filter media for indoor formaldehyde removal. Chem. Phys. Lett. 2020, 757, 137864. [CrossRef]

11. Sun, S.H.; Jung, S.C. Facile synthesis of bimetallic Ni-Cu nanoparticles using liquid phase plasma method. Korean J. Chem. Eng. 2016, 33, 1075-1079. [CrossRef]

12. Kim, S.C.; Park, Y.K.; Kim, B.H.; Kim, H.G.; Lee, W.J.; Lee, H.; Jung, S.C. Facile precipitation of tin oxide nanoparticles on graphene sheet by liquid phase plasma method for enhanced electrochemical properties. Korean J. Chem. Eng. 2018, 35, 750-756. [CrossRef]

13. Ki, S.J.; Park, Y.K.; Kim, J.S.; Lee, W.J.; Lee, H.; Jung, S.C. Facile preparation of tungsten oxide doped TiO 2 photocatalysts using liquid phase plasma process for enhanced degradation of diethyl phthalate. Chem. Eng. J. 2019, 377, 120087. [CrossRef]

14. Lee, H.; Park, I.S.; Bang, H.J.; Park, Y.K.; Kim, H.G.; Ha, H.H.; Kim, B.J.; Jung, S.C. Fabrication of Gd-La codoped TiO 2 composite via a liquid phase plasma method and its application as visible-light photocatalysts. Appl. Surf. Sci. 2019, 471, 893-899. [CrossRef]

15. Ki, S.J.; Lee, H.; Park, Y.K.; Kim, S.J.; An, K.H.; Jung, S.C. Assessing the electrochemical performance of a supercapacitor electrode made of copper oxide and activated carbon using liquid phase plasma. Appl. Surf. Sci. 2018, 446, 243-249. [CrossRef]

16. Chung, K.H.; Park, H.W.; Jeon, K.J.; Park, Y.K.; Jung, S.C. Irradiation of liquid phase plasma on photocatalytic decomposition of acetic acid-containing wastewater over metal oxide photocatalysts. Catal. Today 2018, 307, 131-139. [CrossRef]

17. Lee, H.; Park, S.H.; Seo, S.G.; Kim, S.J.; Kim, S.C.; Park, Y.K.; Jung, S.C. Preparation and characterization of copper nanoparticles via the liquid phase plasma method. Curr. Nanosci. 2014, 10, 7-10. [CrossRef] 
18. Park, Y.K.; Kim, B.J.; Kim, S.C.; You, C.S.; Choi, J.W.; Park, J.G.; Lee, H.; Jung, S.C. Decomposition of naproxen by plasma in liquid process with $\mathrm{TiO}_{2}$ photocatslysts and hydrogen peroxide. Environ. Res. 2021, 195, 110899. [CrossRef]

19. Shuaub, U.; Hussain, T.; Ahmad, R.; Zakaullah, M.; Mubarik, F.E.; Muntaha, S.T.; Ashraf, S. Plasma-liquid synthesis of silver nanoparticles and their antibacterial and antifungal applications. Mater. Res. Express 2020, 7, 035015. [CrossRef]

20. Paula, F.G.F.; Campello-Gomez, I.; Ortega, P.F.R.; Rodriguea-Reinoso, F.; Martinez-Escandell, M.; Silvestre-Albero, J. Structural Flexibility in Activated Carbon Materials Prepared under Harsh Activation Conditions. Materials 2019, 12, 1988. [CrossRef]

21. D'Lima, L.; Phadke, M.; Ashok, V.D. Biogenic silver and silver oxide hybrid nanoparticles: A potential antimicrobial against multi drug-resistant Pseudomonas aeruginosa. New J. Chem. 2020, 44, 4935-4941. [CrossRef]

22. Li, M.; Xue, J. Integrated Synthesis of Nitrogen-Doped Mesoporous Carbon from Melamine Resins with Superior Performance in Supercapacitors. J. Phys. Chem. C 2014, 118, 2507-2517. [CrossRef]

23. Sadri, R.; Hosseini, M.; Kazi, S.N.; Bagheri, S.; Zubir, N.; Solangi, K.H.; Zaharinie, T.; Badarudin, A. A bio-based, facile approach for the preparation of covalently functionalized carbon nanotubes aqueous suspensions and their potential as heat transfer fluids. J. Colloid Interface Sci. 2017, 504, 115-123. [CrossRef] [PubMed]

24. Salvadori, M.R.; Ando, R.A.; Oller Nascimentoc, C.A.; Correa, B. Dead biomass of Amazon yeast: A new insight into bioremediation and recovery of silver by intracellular synthesis of nanoparticles. J. Environ. Sci. Health A 2017, 52, 1112-1120. [CrossRef] [PubMed]

25. Parvizi, R.; Azad, S.; Dashtian, K.; Ghaedi, M.; Heidari, H. Natural Source-Based Graphene as Sensitising Agents for Air Quality Monitoring. Sci. Rep. 2019, 9, 3798. [CrossRef]

26. Prieto, P.; Nistor, V.; Nouneh, K.; Oyama, M.; Abd-Lefdil, M.; Diaz, R. XPS study of silver, nickel and bimetallic silver-nickel nanoparticles prepared by seed-mediated growth. Appl. Surf. Sci. 2012, 258, 8807-8813. [CrossRef]

27. Kaspar, T.C.; Droubay, T.; Chamber, S.A.; Bagus, P.S. Spectroscopic Evidence for Ag(III) in Highly Oxidized Silver Films by X-ray Photoelectron Spectroscopy. J. Phys. Chem. C 2010, 114, 21562-21571. [CrossRef]

28. Ferraria, A.M.; Carapeto, A.P.; Rego, A.M.B. X-ray photoelectron spectroscopy: Silver salts revisited. Vacuum 2012, 86, $1988-1991$. [CrossRef]

29. Zhou, K.; Li, L.; Ma, X.; Mo, Y.; Chen, R.; Li, H.; Li, H. Activated carbons modified by magnesium oxide as highly efficient sorbents for acetone. RSC Adv. 2018, 8, 2922-2932. [CrossRef]

30. Ji, H.Z.; Feng, X.F.; Wu, Y.F.; Li, L.G.; Li, X.; Liu, X. Composite of biomass and lead resistent Aspergillus Oryzae for highly efficient aqueous phase $\mathrm{Pb}$ (II) adsorption. Environ. Prog. Sustain. 2017, 36, 1658-1666. [CrossRef]

31. Baur, G.B.; Yuranov, I.; Kiwi-Minsker, L. Activated carbon fibers modified by metal oxide as effective structured adsorbents for acetaldehyde. Catal. Today 2015, 249, 252-258. [CrossRef]

32. Khaleel, A.; Kapoor, P.N.; Klabunde, K.J. Nanocrystalline metal oxides as new adsorbents for air purification. Nanostruct. Mater. 1999, 11, 459-468. [CrossRef]

33. Hu, Q.; Xie, Y.; Zhang, Z. Modification of breakthrough models in a continuous-flow fixed-bed column: Mathematical characteristics of breakthrough curves and rate profiles. Sep. Purif. Technol. 2020, 238, 116399. [CrossRef]

34. Bohart, G.S.; Adams, E.Q. Some aspects of the behavior of charcoal with respect to chlorine. J. Am. Chem. Soc. 1920, 42, 523-529. [CrossRef]

35. Thomas, H.C. Heterogeneous ion exchange in a flowing system. J. Am. Chem. Soc. 1944, 66, 1664-1666. [CrossRef]

36. Yoon, Y.H.; Nelson, J.H. Application of gas adsorption kinetics I. A theoretical model for respirator cartridge service life. Am. Ind. Hyg. Assoc. J. 1984, 45, 509-516. [CrossRef] [PubMed]

37. Yan, G.Y.; Viraraghavan, T.; Chen, M. A new model for heavy metal removal in a biosorption column. Adsorpt. Sci. Technol. 2001, 19, 25-43. [CrossRef]

38. Clark, R.M. Evaluating the cost and performance of field scale granular activated carbon systems. Environ. Sci. Technol. 1987, 21, 573-580. [CrossRef]

39. Hu, Q.; Huang, Q.; Yang, D.; Liu, H. Prediction of breakthrough curves in a fixed-bed column based on normalized Gudermannian and error functions. J. Mol. Liq. 2021, 323, 115061. [CrossRef]

40. Nelder, J.A.; Mead, R. A simplex method for function minimization. Comput. J. 1965, 7, 308-313. [CrossRef] 